Journal of

Business and Strategic

Management

(JBSM)

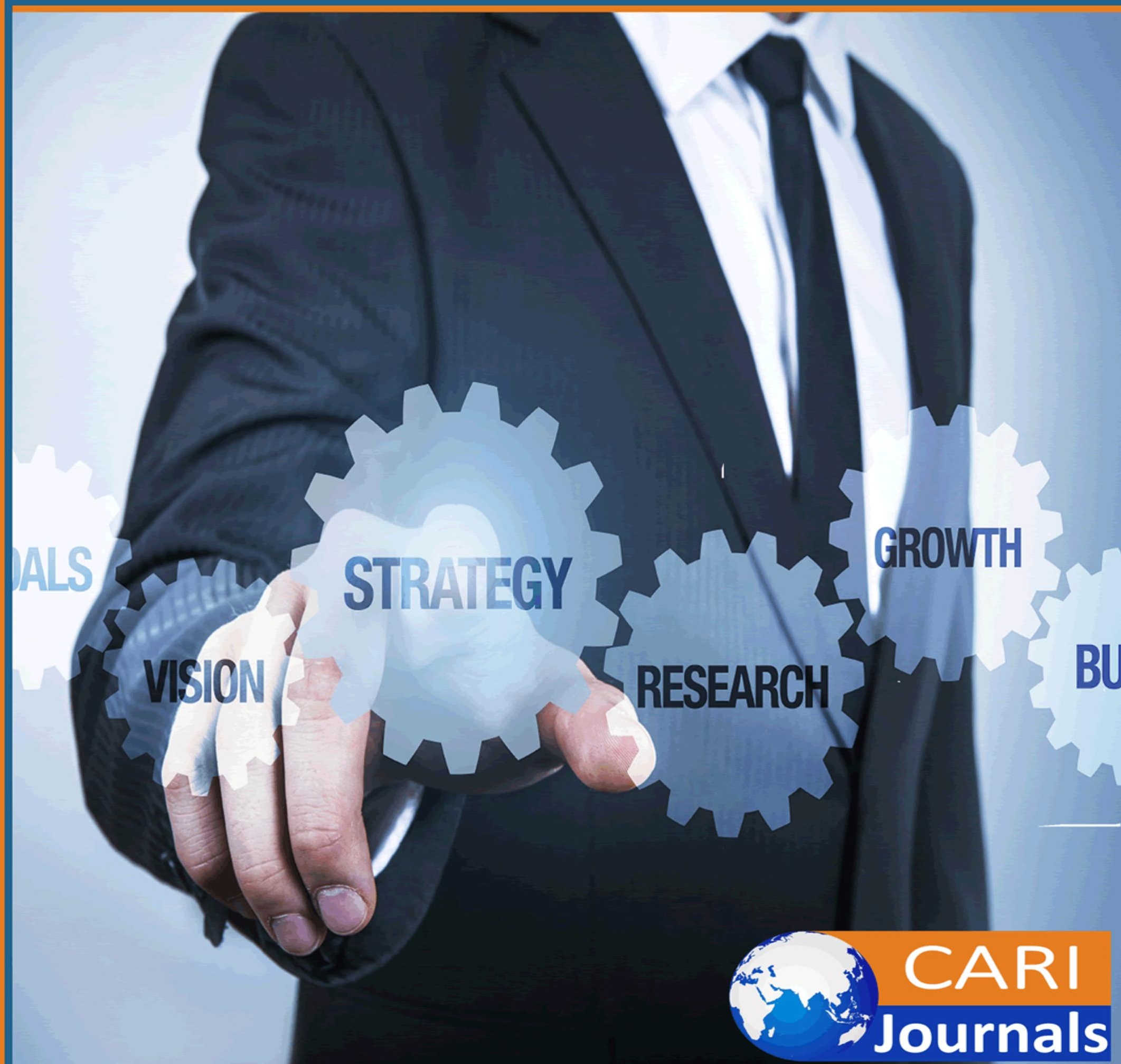




\title{
INFLUENCE OF STUDENT RETENTION STRATEGIES ON PERFORMANCE OF TVETS IN NAIROBI COUNTY, KENYA
}

\author{
1*Christopher Kimeli Magut \\ College of Human Resource and Development, Jomo Kenyatta University of Agriculture and \\ Technology \\ P. O. Box 62000, 00200 Nairobi, Kenya
}

Corresponding Author email: cmagut000@gmail.com

${ }^{2}$ Dr. Allan Kihara

College of Human Resource and Development, Jomo Kenyatta University of Agriculture and Technology

P. O. Box 62000, 00200 Nairobi, Kenya

\begin{abstract}
Purpose: The study sought to evaluate the power of student retention strategies on performance of TVET institutes in Kenya: a case study of Nairobi City County. In order to capture the required information, the study is guided by four objectives; to assess the influence of student orientation and induction strategy, student support programs strategy, customer relation management, and student involvement and participation on performance of TVET institutes in Kenya. This study is anchored on drive reduction theory, tinto's learner's integration theory, the cognitive dissonance theory and structural strain theory.

Methodology: The study used a descriptive survey design utilizing primary quantitative and qualitative data. The study employed stratified and simple sampling techniques on the population. Targeted study population was 182 TVET institutes in Nairobi region with teaching staff and dean of students being unit of observation. 70 institutions were targeted as a sample size by the study. Data was collected through the administration of questionnaires to TVET institutions lecturers and deans of students being the respondents. A pilot study was conducted on 10 randomly selected TVET institutes in Nairobi region equivalent to $6 \%$ of the overall population. Reliability of the research instrument was established through Cronbach's Alpha $(\alpha)$ scale of 0.7 (internal consistency measure) thresholds. Content validity of the instrument was conducted. Descriptive and inferential statistics was used for the purpose of data analysis using Microsoft Excel software and SPSS version 22.0.

Results: The outcomes of the research showed that majority of the sampled staff had attained graduate level of learning, the institution had Student orientation and induction as indicated by $55.75 \%$ of respondents. The institution had in place student support programs as indicated by $40 \%$ of respondents. About $31 \%$ of the sampled population revealed that TVET institutions in
\end{abstract}


Nairobi County had Customer relationship management program and 27\% of the respondents agreed that students were involved to participate on decision making.

Contributions: the study makes contribution to policy in regard to student orientation and induction strategy, student support program strategy, customer relation strategy and student involvement and participation

Key Words: Orientation and Induction Strategy, Support Programs Strategy, Customer Relation Management, Involvement and Participation, TVET Institutes and Performance.

\section{INTRODUCTION}

Crosline, Heagney \& Thomas (2007) in their research found out that TVET institutions across the globe faces the same challenges in maintenance and success of the learners in their studies. This has become a hindrance in the extension of involvement for the underrepresented communities, increasing the learners needs and wants compromising education quality and accountability actions. They further stated that individual impact and life loss are also chances for student's withdrawal from the institutions; financial and family background further contribute to learner's college dropout leading to loss of potential skills and knowledge for the society and the whole economy. TVETS institutes are also affected by finances and reputational implications in their operations. Though learners who did not complete their studies may still acquire skills from TVETs, enhancing their confidence and experiences in life. In the modern competitive and globalized education market, the increasing low retention and high dropout of the learners has affected most TVET institutes worldwide (Qaissie, 2010). Learners' retention has emerged to be a very significant managerial issue particularly as a result of reducing rates of getting new students. Majority of the of higher education institutions has adopted and acknowledged customer retention management in order to deliver superior value for the learners and the institution (Gengeswari, et al 2013). Though the significance of learner's retention differs from institution to the other, all have come to a conclusion that they can achieve a lot of economic objectives by aiming at reducing learner's attritions by doing a survey on the same to improve retention and to communicate or customize interactions with the learners (Gengeswari et al 2013).

Stensaker (2008) said that, to attain quality teaching, institutions should assure learners on quality assurances of the courses, improve on definition and technical processes, considering good teaching practices to enhance student retention. To reduce student attritions, the institutions should spell out the teaching and learning factors to promote student continuation with their earning. Personal factors such as course selection are beyond the teachers or institution, but they me asked on what should be done to increase the possibility of learners continuing with their earning. To improve on quality of education, the institutions need to break its techniques into teaching and guidance to the learners. A collection of issues in modern higher education have an impact on student retention. This factors includes pre entry data, preparation and admission process, student orientations and inductions procedures, study evaluation, social engagements, student assistance including financial and pastoral and improved used of institutional data (Jones, 2008). 
For a long time TVET institutes in the country have sought to both increase and widen participation to include more students from groups that have been less well represented in higher education, while maintaining or improving student retention. There is delicate balance between widening participation to include more students and student retention in these institutions (Mdepa, \& Tshiwula, 2012). On the same note, there is a tension between these priorities, because the students from many low participation groups tend to be less likely to complete their courses for example, drop-out rates after one year are considerably higher for mature students and students from neighborhoods in which there is low participation. There is considerable variation in retention rates of individual higher education institutions. While some institutions have first year drop-out rates in low single-digit figures, others have rates of up to $30 \%$ and even higher for underrepresented groups. This finding points to differing strategies for enhancing student retention and might indicate scope for further improvement (Mdepa, \& Tshiwula, 2012).

\section{Statement of the Problem}

Though, all of the programs and services to help retain students, according American educational sector, center of education tabulations, only $50 \%$ of those who enter higher education actually earn a Bachelor's degree. According to Ministry of Education, science and technology, 2016, the completion rate of students in TVET institutes in Republic of Kenya stands at 55\%, an alarming rate given the role these institutions play an important roles in achieving vision 2030. The report also further indicated that the TVET institutions invest significant institutional resources in students during their course of study, often only to see them leave prematurely leading to reduced performance of the institutes. However, competition among the institutions and from public universities that have joined the fray by opening new colleges in different parts of the country and introducing parallel degree programs in response to spiraling demand for higher education has resulted to colossal loss of students with the need to retain students who join these institutions growing more than ever (Mukhwana, Kande, \& Too, 2017). Student retention is increasingly viewed as a measure of an institution's quality by important external stakeholders including government agencies and the general public. Retention also represents a financial concern for colleges, as funding is closely tied to enrollment levels. Through student retention strategies, TVET institutions are able to deliver superior value for learners as well as the institutions themselves resulting to an improved institutional performance. Student retention strategy is for this purpose often taken to be the main goal for any TVET customer relation strategy and implementation. Kimando, Njogu and Sakwa (2012) reported that there has been a tremendous increase of private universities for last five years, which has been fueled by several factors including limited opportunities available in public universities and the desire to complement public universities. It is clear from these studies that their focus was not on student retention strategies particularly among TVET institutes in Nairobi, Kenya. This study will therefore aim to fill the conceptual research gap by examining the influence of student retention strategies on performance of TVET institutes in Nairobi region. 


\section{Research Objectives}

i) To assess the influence of student orientation and induction strategy on performance of TVET institutes in Nairobi County, Kenya,

ii) To determine the influence of student support program strategy on performance of TVET institutes in Nairobi County, Kenya,

iii) To establish the influence of customer relation strategy, influence the achievements of TVET institutes in Nairobi County, Kenya,

iv) To examine the influence of student involvement and participation on performance of TVET institutes in Nairobi County, Kenya.

\section{LITERATURE REVIEW}

\section{Theoretical Review Drive Reduction Theory (1930s)}

An American psychologist by the name Clark Hull introduced this theory in the 1930's. His works were greatly influenced by behaviorist such as Ivan Pavlov, Edward Thorndike and Edward Tolman. Charles Darwin's Evolution the also played a role in Hull's Drive Reduction Theory. During this time, Hull's theory was very influential. The theory tried to provide a mathematical explanation on all aspects of behavior and the likelihood of its appearance and it used a set of formula to prove this. Hull also conducted several laboratory experiments on hypnosis and he found out that there was complete distinction between hypnosis and sleep.

Although Hull was interested in blatant behavior, he did not rule out the existence of cognitive factors such as ideas, prior knowledge, intelligence, values and insights. His reason for exclusion of these factors was that they could not be scientifically measured. The theory then tries to explain behavior and learning through drive reduction. Drive is an incentive form of a biological need like thirst, hunger, cold and even sexual interest. This state of need according Hull provokes a living organism to behave in certain way so as to reduce the need and may be get back to the ideal biological state. Thus, the drive results to a behavior that aims at satisfying needs or achieving goals. The drive is reduced if its goal is achieved, and this leads to the restoration of an optimal state. Here, the drive reduction serves to be a reinforcer that strengthens the connection between drive and behavior, according to Hull, the reinforced Stimulus-Response (S-R) learning resulting from the reduction of a biological drive is the only kind of learning. Hull's theory was also named as drive reduction theory of motivation as he had a belief that living organisms would always repeat behavior that reduces a drive. This theory typically leaned on S-R relationship and reinforcement. Following an S-R relationship by reducing a drive could probably result to same prior response on similar situations in the future increasing. Through numerous reinforcements, the $S-R$ relationship (habit strength) becomes stronger. Hull viewed biological needs as primary drives, he also believed of the existence of secondary drives (learned drives), which refer to situations associated with the reduction of primary drives. For Hull, a neutral stimulus is capable of bringing about responses that relate to those caused by a primary drive characteristic. 


\section{Tinto Student Integration Theory}

This theory by Tinto (1975) was the most widely discussed and researched model of student retention. As for Braxton (2002), in approximately 70 years of research, much has been done on the question of student retention in higher education and this has led to subsequent development of several theories majorly from the higher education system of the US. Berger and Braxton (1998) point out that Tinto's student integration model has served to be the focus of much empirical research and a virtual hypothesis for attrition among college students. This theory mainly borrowed from Durkheim's (1951) theory of suicide and Spady's (1975) theory of attrition. Tinto's theory appears to be a longitudinal process and it links attrition to the degree to which a student integrates into the university's or college's academic life (Nora, 2000). If attrition is to be reduced in TVET institutions, Tinto (1993) suggests that same level of academic and social integration must occur no matter how both types of integration deviate.

Tinto furthermore expands on the nature of mutuality between these two types of integration. For him, if the relationship that exists between the two types of integration is somehow altered resulting to the student spending too much time on study, then the social integration aspect may suffer. An effect that may lead to dropout. Tinto's theory assumed that a student entered an institution already having individual attributes, background characteristics and prior learning experiences. He then outlines individual attributes as the student's gender, age, race and academic aptitude. Background characteristics referring to the social status of the family, parental formal education and expectation and finally prior learning experiences as what the student has achieved in high school.

For Tinto, if a student is to show commitment to the institution and or achieve his/her academic goals, then it will depend on how the three attributes possessed by the student will associate with each other in the individual student. Likewise, student's degree of commitment may be affected depending on how well that student fits into the social and academic life of the institution. Negative impact may lead to attrition (Tinto, 1975). Among the common reasons as to why college students decide to leave school according to Tinto (1987) are personal, social and financial problems. He suggests that what is more important for the success of a student is how that student is able to slot in new patterns of interaction with members of the new group and show competence in that group as a participant. Tinto (1993) identifies the key roles played by the student TVET institutions, residence hall associations, faculty lecturers and extracurricular programs in reducing dropouts as he observes that institutions may lack formal and informal mechanisms of fitting in the students unlike the way the society does.

\section{The Cognitive Dissonance Theory}

This is a psychological theory developed by a social psychologist Leon Festinger in 1957. This theory has been mentioned in most general and social psychology literature hence proving its plausibility. The theory fits in the action-opinion theories category as it is fairly counterintuitive. For this category of theories, actions can influence successive beliefs and attitudes (Festinger, 1957). Counterintuitive here will mean that our actions are caused by our beliefs and attitudes and not the other way round. These types of theories however have spontaneous appeal in that theories such as cognitive dissonance address the common human affinity to explain. 
The cognitive dissonance theory can be used in different situations which are useful to the human psychology such as; sensitivity to inconsistencies between actions and belief, change of beliefs, change of actions and change of perception of action. If the human nature is not working well then it shows that there is inconsistency between some of the identified elements in the theory. The theory is hence used to identify the needs that should be realigned to improve performance of a human beings through better strategy implementation (Festinger \& Carlsmith, 1959).The theory makes relevance to the study as it highlights the link between strategy alignments with the internal resources of the firm so as to achieve the firm's targets. The development of strategies such as retention strategy as well as its alignment to the organization's processes can lead to the organizations achieving their objectives. The theory therefore emphasizes the need for an organization to have strategies in order to enhance its performance.

\section{Structural Strain Theory}

In his studies focusing on demographic factors, Rumberger $(1983,1987)$ finds out that there is a higher probability that a dropout is a boy and is from a family of low social-economic status. Due to this, Rumberger attributes social factors such as gender, ethnicity and social-economic status as directly having an effect on school dropout besides low academic achievements. As Tesseneer and Tesseneer (1958) puts, same environmental factors can influence students in different ways and during different times. Thus, he cautions against overgeneralizing the complex phenomenon of attrition. Using differential dropout prevention policies can be a solution to dealing with the influence of structural stress factors on attrition (Janosz, Le Blanc, Boulerice and Tremblay, 2000). For Miller (1998) there is a dilemma faced by boys in their school life. He highlights this from the Caribbean where boys start schooling late, attend school unevenly, repeat more grades, drop out earlier have completion rates that are lower and achieve less than what girls achieve while in school. 


\section{Conceptual Framework}

\section{Student Induction}

- Introduction to institutional culture

- Provision of course materials

- Spelling out expectations

\section{Student Support Programs}

- Scholarships and Bursary programs

- Counseling programs

- $\quad$ Student loyalty programs

- Mentoring Programs

Customer Relationship Management

- Student information structure

- Alignment of student incentives

- Speed of solving customer complaints

\section{Student participation and involvement \\ - Involvement in decision making \\ - Student organizations \\ - Opinion surveys}

\section{Independent Variables}

\section{Dependent Variable}

\section{RESEARCH METHODOGY}

The study adopted a descriptive survey design. The study's target population comprised of 182 TVET institutions in Nairobi City County and the unit of observation was deans of students in all of the 182 TVET institutions in Nairobi City. The study adopted a Krejcie and Morgan's (1970) formula in determining the sample of size 70 institutions. The study used structured questionnaires to collect both qualitative and quantitative data captured through a 5-point likert scale. Inferential and descriptive statistics was used to analyze data. Results of the analysis were presented by use of tables and figures. Inferential statistics was used to establish the association between independent variables and dependent variable. The study used the following regression model: 
$Y=\beta_{0}+\beta_{1} X_{1}+\beta_{2} X_{2}+\beta_{3} X_{3}+\beta_{4} X_{4}+\varepsilon$

Where; $\mathrm{Y}=$ Performance of TVET institution, $\mathrm{X}_{1}=$ Student orientation and induction, $\mathrm{X}_{2}=$ Student support programs, $\mathrm{X}_{3}=$ Customer relationship management, $\mathrm{X}_{4}=$ Student involvement and participation, $\varepsilon=$ Error term and $\beta_{0}=$ Constant

\section{RESULTS AND DISCUSSIONS}

The study administered 70 questionnaires where 59 questionnaires were filled and returned. This represented a response rate of $84.3 \%$.

\section{Descriptive Findings and Analysis}

The respondents were asked to indicate the extent to which their respective institutions practiced student retention strategies ranging from orientation and induction strategy, Student support programs strategy, Customer relationship management strategy and Student involvement and participation strategy as well as establish the extent to which various indicators of retention strategies had changed. The responses are on a scale of 1 to 5 where $1=$ strongly agree, $2=$ Agree, $3=$ Neutral, $4=$ disagree and $5=$ strongly disagree. The section presents the mean response of each of the statements.

\section{Descriptive Findings of Student orientation and induction strategy}

This section tests how Student orientation and induction strategy influences retention of students in TVET's learning programs. Table 1 below provides this data. The study showed that $39.7 \%$ of respondents agreed that most of the TVET institutes in Nairobi region guided students through the institution policies, $63 \%$ of respondents strongly agreed that the Students are guided through the institution regulations, over $46 \%$ of respondents agreed there is an effective orientation program for new students based on their religious background, 54\% of respondents agreed that students are guided through the institution lecturing strategies and assessment methods, $31 \%$ of respondents remained neutral on the institutions having appropriate orientation programs for foreign students. Further, over $83 \%$ of respondents agreed that, the student's expectation were clearly spelt out during orientation, $46 \%$ of the respondents agreed that the institutions had reorientation programs on new developments and procedures, $57 \%$ of the respondents agreed that, there was an effective orientation/induction program for career development while over $83 \%$ of the respondents agreed that students are provided with the necessary materials such as course guidelines and learner introduction handbooks and over $83 \%$ of the respondents agreed that most TVET institutes in Nairobi region clearly spelt out mission and vision to the students during early induction. On average $55.75 \%$ of the respondents agreed on all aspects.

On average, it can be concluded that Student orientation and induction strategy is practiced commonly by the TVET institutions in Nairobi County - Kenya as revealed by an average mean of 32.364 a standard deviation of 5.422 showed that there was less variation on opinions student retention strategy. This collaborates study by Kuh, Kinzie, Schuh \& Whitt (2011) who indicated that, it is important to have a clear and structured induction strategy at universities to help 
promote the integration of students to their academic life to reduce any kind of culture shock. Students in many cases are living away from their homes and families, more often than not for the first time. For many international students the situation is of course multiplied. Not only do they have to come to terms with living away from home, but so far removed from home in a strange country. They will need to contend with a new language, a very different culture from their own, and deal with people from varied cultural backgrounds. Many international students tend to need more support than national [local] students.

This collaborates study by Ngome (2009) who indicated that the quality of staff is affecting the ability of TVET institutions to accomplish their role in society. He further indicated that, proper and clear guidelines on rules and regulations are vital for new students, encourage general answer and questions sessions for slow learners, the use additivity to provide personalized experiences, use instructor friendly tools such as; what you see is what you get 'WHYISWYG' it's a presentation tool, hiring some of the best tutors who will leave an impact on the learners and publish the exercise on the notice board, social media etc. to ensure maximum attendance of all new learners. This agrees with report by Opiyo.S. (2013), also relates how it is important to have an induction strategy whereby the environment of the university is perceived by students as supportive and friendly. The first year is the most important for students and support must be given at this time. It is also important that social aspects must be considered in relation to studies. The report further indicated that, induction and orientation is very important at the beginning of every new entry to college, discuss the institutions programs with students and update the institution website with general information to help guide the students.

Table 1: Introduction to Institutional culture

\begin{tabular}{lll}
\hline Indicators of student retention strategy & Average & Std. Dev. \\
\hline Students institutional policies guidance & 38 & 5.64 \\
Students institution regulations guidance & 44 & 11.64 \\
Effective orientation for new students on religious background & 20 & 12.36 \\
Institution lecturing strategies and evaluating techniques & 38 & 5.64 \\
Appropriate orientation programs for foreign students & 18 & 14.36 \\
The expectations of the students are clearly spelt out on day one. & 32 & 0.36 \\
student's expectations clearly spelt out on day one & 32 & 0.36 \\
Re-orientation programs on new developments and procedures & 40 & 7.64 \\
Effective orientation/induction program for career development & 30 & 2.36 \\
Provision of necessary materials (course guidelines \& References) & 30 & 2.36 \\
clear definition of institutional values and beliefs. & 34 & 1.64 \\
Mean & & \\
\hline
\end{tabular}

\section{Descriptive Findings on Student support programs strategy}

The respondents were requested to indicate the present of student support programs in the institution. Table 2 below provides this data. The study showed that $46 \%$ of the respondents agreed that most of the TVET institutes in Nairobi region partners with stakeholders to secure students scholarships while $37 \%$ of the respondents agreed that the institutions partners with 
stakeholders to secure students bursary funds, over $37 \%$ of the respondents agreed that the institutions has in place reliable student religious counseling programs, 46 of the respondents agreed The institution has student loyalty programs to award student in various areas of responsibility while $47 \%$ of the representing of the respondents agreed that TVET institutes in Nairobi region had appropriate student mentoring programs to nurture unique talents. Additional, over $48 \%$ of the respondents agreed that, the TVET institutes in Nairobi region has in place reliable student moral and emotional counseling programs while $34 \%$ of the respondents agreed that the institutions. The institution has in place appropriate processes to identify needy students. On average $42 \%$ of the respondents remained neutral on all aspects. On average, it can be concluded that Student support programs strategy is practiced to a high extent by the TVET institutions in Nairobi County - Kenya as revealed by an average mean of 30.29. A standard deviation of 2.53 showed that there was less variation on opinions student retention strategy.

This agrees with Pitt, Powis, Levett-Jones \& Hunter, (2012) who stated that in most student support programs, students are supported at registration, during their studies, and at exit level. Among the support programs in TVET institutions include: student induction programs, educational advising, library assistance, study skills, examination, language assistance, computer assistance, placement, occupational and subject choices, financial aid \& bursaries, entrepreneurial skills training, sport assistance, cultural activities, and social adjustment. This collaborates with study by Mahlo (2011) who stated that student support services are organized in a system to assist individual colleges so that their education can be more effective. Education support services as part and parcel of the entire school practice include all human, provide quality services by organizing internship after completion of study, form clubs that the students can be identified with, doing follow up on student's general performance, make use of the suggestion box, encourage student evaluation on quality of services they are receiving, work study programs for those with financial constraints, outdoor sporting activities to expose stundents to outside world, career days/ activities with interested professionals, in areas of specialized teaching, strong alumni to help all the youngest as they graduate out of college.

This agrees with Steyn, (2014) who stated that through vocational guidance and counseling students need to know which occupations and jobs are best suited towards their interests, values, and skills, and they have to understand the kind of qualifications and personal attributes required. These are attained through; links with potential employers through attachment or internship, firsthand experience in collaboration with other organization or institutions to sharpen their skills ready for job market, establishing links between alumni and provide for collaboration and sharing and engage more on funding e.g. HELB so that the students don't drop due to lack of funds. Students be assisted in and other resources that provide support to individual student's other aspects of the education system. 
Table 2: Student Support Programs Strategy

\begin{tabular}{|c|c|c|}
\hline Indicators of student retention strategy & Average & Std Dev \\
\hline Institution partners with stakeholders to secure students scholarships & 32 & 1.71 \\
\hline Institution partners with stakeholders to secure students bursary funds & 26 & 4.29 \\
\hline Institution has in place reliable student religious counseling programs & 26 & 4.29 \\
\hline Student loyalty programs to award student in various disciplines & 32 & 1.71 \\
\hline Student mentoring programs to nurture unique talents & 34 & 3.71 \\
\hline Appropriate coaching programs to nurture the talents of the students & 32 & 1.71 \\
\hline Reliable student moral and emotional counseling programs & 30 & 0.29 \\
\hline Mean & 30.29 & 2.53 \\
\hline
\end{tabular}

\section{Descriptive Findings on Customer relationship management strategy}

This section tested on how customer relationship management strategy influences retention of and performance of students in TVET institutes in Nairobi region. Table 3 below provides this data. The study disclosed that $46 \%$ of the respondents agreed that most of the TVET institutes in Nairobi region used incentives to support customer relationship building with the students while $49 \%$ of the respondents agreed that the institutions the institution took a long term view to the formation of student relationships, $48 \%$ of the respondents strongly agreed that the institutions allowed students to do so face-to-face when interacting with the administration, about $80 \%$ of the respondents representing of the total sampled population agreed the institutions had invested in IT for the purpose of enhancing student relationships. Also, $47 \%$ of the sampled population agreed that TVET institutes in Nairobi region frequently use relevant models in evaluation of student relationships with the administration while $51 \%$ of the respondents agreed that TVET institutes in Nairobi region used formal system of evaluating the prospects of students to improve their performance but $40 \%$ of the respondents used formal system of re-establishing closer relationships with students. On average $31 \%$ of the respondents strongly agreed on all aspects while $7 \%$ of the respondents representing totally disagreed on every aspect.

This agrees with Miyandazi, M. (2013) who reported that, with upcoming change in technology, marketing strategies change simultaneously for the TVET institutes. Current marketing is based on acquiring knowledge on students need. CRM is termed as a cycle containing significant functions such as knowledge search, planning for new markets, improving student cohesions, timely service delivery to learners to avoid frustrating the student, open student relation office, increase more team building activities, having frequent meeting and follow up meetings with students, Establishment of student leadership office, improve interactions of administration and students in informal setup, students to be given mentors and advisors on campus events, Keep a complaint and complement books to avoid recurrence of mistakes and analysis refinement. This collaborates study by Noel Yee-Man Siu (2016) who reported there is need for good customer relation management between student and institutional management to reduce student attrition ad to enhance retention by delivering superior and quality education service to the learners. 
Table 3: Customer relations management strategy on performance of TVET

\begin{tabular}{lll}
\hline Indicators of student retention strategy & Mean & Std Dev \\
\hline Use of Student incentives by institution as customer relationship building. & 32 & 0.286 \\
Long term assessment on formation of student relationships & 34 & 1.714 \\
Student interaction with institution management & 34 & 1.714 \\
The institution has invested in IT to enhancing student relationships & 28 & 4.286 \\
Use of relevant models in evaluation of student relationships \& adm. & 34 & 1.714 \\
Formal system of evaluating students prospects to improve their performance & 36 & 3.714 \\
There is a formal system of re-establishing closer relationships with students & 28 & 4.286 \\
Average & $\mathbf{3 2 . 2 9}$ & $\mathbf{2 . 5 3}$ \\
\hline
\end{tabular}

\section{Descriptive Findings on Student involvement and participation strategy}

This section established how student involvement and participation strategy to attract, retain students and also to improve the performance of the students in TVET institutes in Nairobi region. Table 4.8 shows their feedbacks. The study revealed that $34 \%$ of the respondents remained neutral on the fact that most of the TVET institutes in Nairobi region had in place appropriate procedures to involve students in making key decisions while $54 \%$ of the respondents agreed that the institutions involves students in the formation of various student leadership positions, $40 \%$ of the respondents strongly agreed that most TVET institutes in Nairobi region factored in the contributions of student's leaders in decision making. About 34\% of the participants making of sampled population agreed the institutions regularly conducts opinion survey to obtain views of students regarding the operations of the institution while $40 \%$ of the respondents representing of the sampled population remained neutral on how the institutions allowed student representatives into AGMs while $37 \%$ of the respondents representing of the sampled population remained neutral on the fact that TVET institutes in Nairobi region provides adequate financial support to student organizations. On average $27 \%$ of the respondents of the sampled TVET institutes in Nairobi region remained neutral on sensitive issues like involving students on decision making and utilization of finances.

This agrees with Kirimi (2012) who indicated that financing TVET institutes programs has always been shared amongst government, local communities, beneficiaries, religious and private organizations, donors and private business. This is supported by Jeruto \& Kiprop (2011) who acknowledged that student representation during institutional decision making is the responsibility of the student leaders. This gives students a chance to express their views, performance of appraisal of student's leaders involving student leaders in AGMs 
Table 4: Student involvement and participation strategy on TVET institutions

\begin{tabular}{lll}
\hline Indicators of student retention strategy & Mean & Std Dev \\
\hline Students involvement in institution decision making. & 22 & 0.66 \\
Students involvement information student leadership positions & 38 & 15.333 \\
Student leaders' contributions in decision making of the institution. & 28 & 5.333 \\
Opinion survey conducted to obtain student feedback by institution & 24 & 1.333 \\
The institutions allows student representatives into AGMs & 10 & 12.667 \\
The institution provides adequate financial support to student organizations & 14 & 8.667 \\
Average & $\mathbf{2 2 . 6 7}$ & $\mathbf{7 . 3 3}$ \\
\hline
\end{tabular}

\section{Descriptive Findings on Performance of TVET institutes in Nairobi region}

This section established how performance attracts and retain students in TVET institutes in Nairobi region. Table 4.9 shows their feedbacks. The study revealed that $53 \%$ of the respondents agreed that most of the TVET institutes in Nairobi region had improved on student course completion rate while $54 \%$ of the respondents agreed that the institutions had significantly improved on its student intake, 50\% of the respondents strongly agreed that most TVET institutes in Nairobi region agreed that the institution has succeeded at generating more revenue. Approximately $51 \%$ of the respondents representing of the total sampled population agreed that the TVET institutes in Nairobi region had reduced the cost of transacting with students while $37 \%$ of the respondents representing of the sampled population agreed that the costs incurred in securing new students to the institution had significantly reduced while $46 \%$ of the respondents representing of the sampled population remained agreed that TVET institutes in Nairobi region had significantly improved on student perception of delivery of services by the institution. Study also revealed that $59 \%$ of the respondents representing of the sampled TVET institutes in Nairobi region had improved on the process of responding to the student complaints, $48 \%$ of the respondents representing of the sampled institutions agreed that the position of the institution with regard to other rival institutions had significantly improved and 54\% of the respondents representing of the sampled population agreed that most TVET institutes in Nairobi region had gained significant influence on the education sector in the region. On average $50 \%$ of the respondents agreed on all aspects. 
Table 5: Performance of TVET institutes in Nairobi region

\begin{tabular}{lll}
\hline Statements & Mean & Std Dev \\
\hline There is an improvement in learner's completion rate. & 38 & 5.333 \\
The institute has improved on learner's admissions. & 38 & 5.333 \\
The institute has prospered at making more revenue. & 34 & 1.333 \\
There is a greater reduction in cost of managing students & 36 & 3.333 \\
The costs of acquiring new students to the institution has reduced & 24 & 8.667 \\
Institution service delivery has significantly improved & 32 & 0.667 \\
Institution student complaints response has improved & 38 & 5.333 \\
The institution leads rival institutions & 34 & 1.333 \\
The institution has influence on education sector in the region & 38 & 5.333 \\
Average & $\mathbf{3 4 . 6 7}$ & $\mathbf{4 . 0 7}$ \\
\hline
\end{tabular}

\section{Inferential Analysis}

\section{Correlation Analysis}

Cohen, West and Aiken (2013) argued that correlation indicates the direction in one variable if another variable changes. A positive Pearson correlation value indicates a positive correlation while a negative Pearson correlation value indicates negative correlation. The strength of the association increases as the value approaches either negative 1 or positive 1 . The study conducted a correlation analysis to establish the association among the variables used in the study. The study findings on correlation are as presented in Table 6.

The study findings revealed a positive and significant relationship between Student orientation and induction strategy and performance of TVET institutions (Pearson Coefficient $=0.2785$, Sig $=0.000,<0.05)$. These findings imply that an improvement in spelling out institutional policies and regulations students, having effective orientation for new students on religious background, improving on lecturing strategies and evaluating techniques, having appropriate orientation programs for foreign students, re-orientation programs on new developments and procedures of the institution, having effective orientation/induction program for career development, provision of necessary materials (course guidelines \& References), mission, vision, values and beliefs are clearly spelt out during early induction leads to improvement in performance of the students in TVET institutes in Nairobi City County - Kenya. The study findings also showed that there is a positive and significant relationship between Student support programs strategy and performance of TVET institutions in Nairobi City County - Kenya (Pearson Coefficient $=0.469$, Sig $=0.012$, $<0.05)$. These findings imply that an improvement in Student support programs strategy practices such as securing scholarships and bursaries for needy students, religious counseling programs, coming up with student loyalty programs to award student in various disciplines, putting in place student mentoring programs to nurture unique talents, appropriate coaching programs to nurture the talents of the students, reliable student moral and emotional counseling programs leads to improvement in performance of the students in TVET institutes in Nairobi City County - Kenya. 
Further findings showed a negative and significant relationship between Customer relationship management (CRM) and Student involvement and participation TVET institutes in Nairobi City County - Kenya. (Pearson Coefficient $=0.4109$, Sig $=0.002,<0.05$ ). These findings imply that an improvement in Customer relationship management strategy practices such as use of Student incentives by institution to support customer relationship building, taking long term view to the formation of student relationships, students interacting with the administration of the institution, institution has invested in IT for the purpose of enhancing student relationships, frequent use of relevant models in evaluation of student relationships with the administration, use of formal system of evaluating the prospects of students plays a lesser role in performance of the students in TVET institutes in Nairobi City County - Kenya. Lastly, it was revealed that there is a positive and significant relationship between Student involvement and participation Strategy and performance of the students in TVET institutes in Nairobi City County - Kenya. (Pearson Coefficient $=0.3925$, Sig $=0.041,<0.05)$. The findings imply that an improvement in Student involvement and participation Strategy practices such as involving students in key decisions making of the institution; regularly conducting opinion survey to obtain views of students regarding the operations of the institution, providing adequate financial support to student organizations, institution involving students in the formation of various student leadership positions significant improvement in performance of the students in TVET institutes in Nairobi City County - Kenya.

\section{Table 6 Correlation Analysis}

\begin{tabular}{|c|c|c|c|c|c|c|}
\hline & & $\begin{array}{l}\text { Student } \\
\text { orientation } \\
\text { and } \\
\text { induction } \\
\text { Strategy }\end{array}$ & $\begin{array}{l}\text { Student } \\
\text { support } \\
\text { programs } \\
\text { strategy }\end{array}$ & $\begin{array}{l}\text { Customer } \\
\text { relationship } \\
\text { manageme } \\
\text { nt }(\text { CRM }) \\
\end{array}$ & $\begin{array}{l}\text { Student } \\
\text { involveme } \\
\text { nt and } \\
\text { participati } \\
\text { on } \\
\text { Strategy } \\
\end{array}$ & $\begin{array}{l}\text { Performanc } \\
\text { e of TVET } \\
\text { institution }\end{array}$ \\
\hline $\begin{array}{l}\text { Student orientation and } \\
\text { induction }\end{array}$ & $\begin{array}{l}\text { Pearson } \\
\text { Corr. }\end{array}$ & 1 & & & & \\
\hline $\begin{array}{l}\text { Student } \\
\text { programs }\end{array}$ & $\begin{array}{l}\text { Pearson } \\
\text { Corr. }\end{array}$ & 0.6879 & 1 & & & \\
\hline $\begin{array}{l}\text { Customer relationship } \\
\text { management } \\
\text { (CRM)Strategy }\end{array}$ & $\begin{array}{l}\text { Pearson } \\
\text { Corr. }\end{array}$ & -0.3963 & 0.6879 & 1 & & \\
\hline $\begin{array}{l}\text { Student involvement and } \\
\text { participation }\end{array}$ & $\begin{array}{l}\text { Pearson } \\
\text { Corr. }\end{array}$ & 0.3193 & 0.4085 & -0.3888 & 1 & \\
\hline $\begin{array}{l}\text { Performance of TVET } \\
\text { institution }\end{array}$ & $\begin{array}{l}\text { Pearson } \\
\text { Corr. }\end{array}$ & 0.2785 & 0.469 & 0.4109 & 0.3925 & 1 \\
\hline & $\mathrm{N}$ & 59 & 59 & 59 & 59 & 59 \\
\hline
\end{tabular}




\section{Regression Analysis}

The study adopted regression analysis to test the significance levels of each independent variable against dependent variable. The model summary findings presented in Table 7 revealed that the four independent variables (Student orientation and induction strategy, Student support programs strategy, Customer relationship management strategy and Student involvement and participation Strategy) jointly had a strong positive effect on Performance of TVET as shown by a joint Pearson correlation of 0.6881. This implies that an improvement in all the four common strategies (Student orientation and induction strategy, Student support programs strategy, Customer relationship management strategy and Student involvement and participation Strategy) will result in an improvement in Performance of TVET institutions in Nairobi City County Kenya. The coefficient of determination (R-square) was 0.1688 implying that common strategies, that is, Student orientation and induction strategy, Student support programs strategy, Customer relationship management strategy and Student involvement and participation Strategy jointly account for up to $56.9 \%$ of the Performance of TVET institutions in Nairobi City County - Kenya. The difference is accounted for by other variables other than the four generic strategies.

Table 7 Model Summary

\begin{tabular}{llll}
\hline R & R Square & Adjusted R Square & $\begin{array}{l}\text { Std. Error of the } \\
\text { Estimate }\end{array}$ \\
\hline 0.6881 & 0.569 & 0.507 & 0.806
\end{tabular}

Predictors: (Constant), Student orientation and induction, Student support programs, Customer relationship management, Student involvement and participation

The F statistic indicating the overall significance of the model is significant at $5 \%$ (Sig $=0.000$, $<0.000$ ) showing that the model linking general strategy improvement in Performance of TVET institutions in Nairobi City County - Kenya was significant. The F calculated statistic of 14.559> $\mathrm{F}$ critical $\left(\mathrm{F}_{4}, 54\right)$ value of 2.650 confirming that the model was significant at $5 \%$. The model significance results therefore imply that the four general strategies (Student orientation and induction, Student support programs, Customer relationship management, Student involvement and participation) used in this study are suitable factors in predicting improvement in performance of TVET institutions in Nairobi City County - Kenya.

Table 8: ANOVA (Model Significance)

\begin{tabular}{llllll}
\hline Indicator & $\begin{array}{l}\text { Sum } \\
\text { of Squares }\end{array}$ & df & $\begin{array}{l}\text { Mean } \\
\text { Square }\end{array}$ & F & Sig. \\
\hline Regression & 4180.2043 & 4 & 1045.0511 & 14.5593 & .000 \\
Residual & 2440.4821 & 54 & 71.7789 & & \\
Total & 6620.6864 & 58 & & &
\end{tabular}

Dependent Variable: Student retention strategies

Predictors: (Constant), Student orientation and induction, Student support programs, Customer relationship management, Student involvement and participation. 
The regression results presented in Table 4.13 revealed that Student orientation and induction had a positive $($ Beta $=1.969)$ and significant $(\mathrm{Sig}=0.000<0.05)$ relationship with Performance of TVET institutions in Nairobi City County - Kenya. This implies that a unit improvement in Student orientation and induction leads to a 1.969 units enhancement in performance of TVET institutions in Nairobi City County - Kenya. From the research, it was also established that Student support programs strategy had a positive $($ Beta $=3.049)$ and significant $(\mathrm{Sig}=0.012,<$ 0.05) relationship with Performance of TVET institutions in Nairobi City County - Kenya. This implies that a unit improvement in diversification strategy leads to a 3.049 units improvement in with Performance of TVET institutions in Nairobi City County - Kenya.

The findings also showed that Customer relationship management strategy had a positive (Beta $=$ 1.960) and significant $(\mathrm{Sig}=0.002,<0.05)$ relationship with Performance of TVET institutions in Nairobi City County - Kenya. This implies that a unit improvement in diversification strategy leads to a 1.960 units improvement in with Performance of TVET institutions in Nairobi City County - Kenya. Lastly, it was established that Student involvement \& participation strategy had a positive $($ Beta $=3.170)$ but not significant $(\mathrm{Sig}=0.041,<0.05)$ relationship with Performance of TVET institutions in Nairobi City County - Kenya. This implies that a unit improvement in Student involvement \& participation leads to an insignificant improvement in Performance of TVET institutions in Nairobi City County - Kenya by 3.170 units.

Table 9: Regression Coefficients

\begin{tabular}{|c|c|c|c|c|c|}
\hline & \multicolumn{2}{|c|}{$\begin{array}{l}\text { Unstandardized } \\
\text { Coefficients }\end{array}$} & \multicolumn{2}{|c|}{$\begin{array}{l}\text { Standardized } \\
\text { Coefficients }\end{array}$} & \multirow[b]{2}{*}{ Sig. } \\
\hline & B & Std. Error & Beta & $\mathbf{t}$ & \\
\hline (Constant) & 0.891 & 0.567 & & 1.571 & 0.049 \\
\hline Student orientation and induction & 1.969 & 0.357 & 0.828 & 5.515 & 0.000 \\
\hline Student support programs & 3.049 & 1.769 & 0.001 & 1.724 & 0.012 \\
\hline Customer relationship management & 1.960 & 0.538 & 0.000 & 3.643 & 0.002 \\
\hline $\begin{array}{l}\begin{array}{l}\text { Student } \\
\text { participation }\end{array}\end{array}$ & 3.170 & 2.933 & 0.046 & 1.081 & 0.041 \\
\hline Dependent Variable: Performance & f TVET & astitutions & County. & & \\
\hline
\end{tabular}

Based on the collected and tested data, the following revised regression model was arrived at:

Performance of TVET $=\mathbf{0 . 8 9 1}+1.969$ (Student involvement \& participation) +3.049 (Student support programs) + 1.960 (Customer relationship management) + 3.170 (Student involvement \& participation)

In order of significance based on the values of t-statistics, it was revealed that Student involvement \& participation strategy had the most significant effect on Performance of TVET, followed by Student support programs strategy, Student involvement \& participation in thirdly position and lastly Customer relationship management strategy. 


\section{CONCLUSION AND RECOMMENDATIONS}

\section{Conclusion}

The study findings led to the conclusion that an improvement in Student orientation and induction strategy practices such as focusing on students institutional policies guidance, Students institution regulations guidance, Effective orientation for new students on religious background, Institution lecturing strategies and evaluating techniques, Appropriate orientation programs for foreign students, Re-orientation programs on new developments and procedures, Effective orientation/induction program for career development and Provision of necessary materials (course guidelines \& References) of technical and vocational education and training in Nairobi County - Kenya. It can also be concluded that an improvement in student support programs strategy practices such as institution partners with stakeholders to secure students scholarships and bursaries, putting in place reliable student religious counseling programs, loyalty programs to award student in various disciplines, Student mentoring programs to nurture unique talents, appropriate coaching programs to nurture the talents of the students and reliable student moral and emotional counseling programs leads to an improvement in performance of technical and vocational education and training institutions in Nairobi County - Kenya.

The study findings on customer relation management strategy further led to the conclusion that an improvement in customer relation management strategy practices such as use of student incentives by institution as customer relationship building, student interaction with institution management, investing in IT to enhancing student relationships, use of relevant models in evaluation of student relationships and administration leads to an improvement in performance of technical and vocational education and training institutions in Nairobi County - Kenya. It was lastly concluded that an improvement in student involvement and participation strategy practices such as Students involvement in institution decision making, students involvement in formation student leadership positions, students leaders contributions in decision making of the institution and conducting opinion survey conducted to obtain student feedback by institution will enhance the performance of TVET institutions in Nairobi City county of Kenya.

\section{Recommendations of the study}

This section presents recommendations for policy and action. The study aimed to provide recommendations to the management of the TVET institutions, policy makers as well as stake holder in technical education and vocational training in regard to broad strategies and TVET performance. The section mainly based on the study findings and is presented per objective. In order for TVET institutions in Nairobi City County to enhance their performance through Student orientation and induction strategy, there is a need to focus on Introduction to institutional culture, provision of course materials and spelling out expectations which are some of the tested performance practices. 
It can also be recommended that in order for TVET institutions in Nairobi City County to enhance their performances and student retention through Student support programs strategy there is a need to enhance Scholarships and Bursary programs, Counseling programs, Student loyalty programs, Mentoring Programs which have been tested and proven to enhance performance e by this study. The study also recommends TVET institutions in Nairobi City County to enhance their student retention and performance through improvement in Customer relation management strategy practices such as student information structure, alignment of student incentives and Speed of solving customer complaints since the study has established a greater positive effect. The study also recommends TVET institutions both private and public to practice Student involvement and participation strategy more in terms of concentrating on Involvement in decision making, Student organizations, and Opinion surveys since it will positively improve TVET performance although not to a big margin.

\section{ACKNOWLEDGEMENT}

I express my sincere thanks to Dr. Allan Kihara for his help with my thesis and to have trusted me by signing this thesis. He was always patient, time-giving and information sharing. His sense of humor and sound knowledge about strategic management its applications gave me the confidence I needed. I would like to thank my brothers, Eliud Kipkosgei Kutto, Edward Kipchumba Magut, Sisters, Rodah Jepkemboi, Ann Jemesunde and Mercy Jepkoech for having supported all my decisions all along my life and let me be myself without judging me, I could not be successful without them.

\section{REFERENCES}

Afeti, G (2014) 'Technical and Vocational Education programs and Training for industrialization'. African Research and Resource Forum (ARRF), Nairobi Kenya.

Badenhorst, J. W. \& Radile, R. S. (2018) 'Poor performance at TVET colleges', conceptualizing a distributed.

Badenhorst, J. W., \& Radile, R. S. (2018). Poor Performance at TVET Colleges: Conceptualizing a Distributed Instructional Leadership Approach as a Solution. Africa Education Review, 1-22.

Brodhead, C. W. (2000) A Vision for Vocational Education." Vocational Education Journal 66(1), 22-25.

Buzzell, C.H. (1987) "Let Our Image Reflect Our Pride." Vocational Education Journal 62(8)10.

Bwisa, H (2014). Challenges of managing Youth Polytechnics. Entrepreneurship Department, Jomo Kenyatta University of Agriculture and Technology, Kenya.

Clack, H. (2009). Student Induction Strategies.

Crosling, G., Heagney, M., \& Thomas, L. (2009). Improving student retention in higher education: Improving teaching and learning. Australian Universities' Review, 51(2), 9.

Diaa, E.L. (2006). Education programs Finance in Egypt. Dakar: Codesria, Egypt. 
Drake, J. K. (2011). The role of academic advising in student retention and persistence. About Campus, 16(3), 8-12.

Hassanien, A., \& Barber, A. (2008). An evaluation of student induction in higher education. International Journal of Management Education, 6(3), 35.

Ibrahim, A. (2012). An empirical analysis on the operational challenges of interest free banking window in Nigeria: Department of General Studies, Federal Polytechnic, Nasarawa, Nasarawa State, Nigeria.

Ingersoll, R. M., \& Strong, M. (2011). The impact of induction and mentoring programs for beginning teachers: A critical review of the research. Review of educational research, 81(2), 201-233.

Jones, R (2008), 'Widening Participation - Student retention and success', Research Synthesis for the Higher Education Academy:

KENPRO (2013). Research Ethical Consideration. Kenya Projects Organization, Nairobi, Kenya.

Kincheloe, Joe L (1995). Toil and Trouble: Good Work, Smart Workers, and the Integration of Academic and Vocational Education. New York: Peter Lang Publishing.

Kincheloe, Joe L. (1999) How Do We Tell the Workers? The Socio-Economic Foundations of Work and Vocational Education. Boulder, CO: Westview Press.

Kirimi.T (2012) Alternative financing mechanisms in provision of quality education programs and training in youth polytechnics. Kenyatta University, Kenya.

Kitui, M. B. (2015). Factors Influencing Access to Technical and Vocational Education and Training in Bungoma East Sub-County, Kenya (Doctoral dissertation, University of Nairobi).

Konings, P. (2002). University students' revolt, ethnic militia, and violence during political liberalization in Cameroon. African Studies Review, 45(2), 179-204.

Kuh, G. D., Kinzie, J., Schuh, J. H., \& Whitt, E. J. (2011). Student success in college: Creating conditions that matter. John Wiley \& Sons.

Lauglo, Jon; Maclean, Rupert (2005) (Eds.) "Vocationalisation of Secondary Education Revisited". Series: Technical and Vocational Education and Training: Issues, Concerns and Prospects.

Luescher-Mamashela, T. M. (2013). Student representation in university decision making: good reasons, a new lens?. Studies in Higher Education, 38(10), 1442-1456.

Maimane, J. R. (2016). The Impact of Student Support Services on Students Enrolled for National Certificate Vocational in Motheo District, Free State, South Africa. Universal Journal of Educational Research, 4(7), 1680-1686.

Manogharan, M. W., \& Varadarajan, S. (2018). The Effect of Customer Relationship Management on Customer retention in Private Higher Education Institute in 
Malaysia. International Journal of Research In Education Methodology, 9(1), 14411453.

Marope, P.T.M; Chakroun, B.; Holmes, K.P. (2015). Unleashing the Potential: Transforming Technical and Vocational Education and Training. UNESCO.

Mati, A., Gatumu, J. C., \& Chandi, J. R. (2016). Students' Involvement in Decision Making and Their Academic Performance in Embu West Sub-County of Kenya. Universal Journal of Educational Research, 4(10), 2300-2304.

Matthews, David (2017), Europeans back funding vocational training over higher education, Times Higher Education, retrieved 3 June 2017

McLeskey, J. L., Rosenberg, M. S., \& Westling, D. L. (2017). Inclusion: Effective practices for all students. Pearson.

Mdepa, W., \& Tshiwula, L. (2012). Student diversity in South African higher education. Widening participation and lifelong learning, 13(1), 19-33.

Ministry of education programs (2012). Aligning education programs and Training to the Constitution of Kenya (2010) and Kenya Vision 2030 and beyond. A Policy Framework for education programs, Nairobi, Kenya.

Ministry of Higher education programs, Science Technology (2012). A Policy Framework for education programs and Training. Reforming education programs and Training in Kenya. Ministry of Higher education programs, Science Technology, Nairobi, Kenya.

Ministry of Youth Affairs and Sports (2012). Youth Polytechnics Training. Youth Department, Nairobi, Kenya.

Miyandazi, M (2013). Influence of entrepreneurial skills on the achievement of the design sector. The University of Nairobi, Kenya.

Mpanza, N. M. (2017). Evaluation of quality administrative practices in three selected Technical and Vocational Education and Training colleges in KwaZulu-Natal (Doctoral dissertation).

Mugenda, O.M. and Mugenda, A.G. (1999). Research Methods: Quantitative and Qualitative Approaches. Acts Press, Nairobi.

Mugenda,O. M. and Mugenda, A. G. (2003). Research Methods: Quantitative and Qualitative Approaches. Acts Press, Nairobi.

Mukhwana, E. J., Kande, A., \& Too, J. (2017). Transforming University Education in Africa: Lessons from Kenya. African Journal of Rural Development, 2(3), 341-352.

Ngome,C (2009). Overview of Skills Development in Kenya: Constraints and Prospects Eastern Africa on Basic and Post. Bureau of education programsal Research Kenyatta University, Nairobi. 
Nida-Rümelin, Julian (2009)"Learning for Jobs OECD review of Australian vocational education" (PDF). Oecd.org. Retrieved 2016-02-06.

Nyerere,J (2009). Technical and vocational education programs and training sector mapping in Kenya. Dutch Schokland Tvet education programs Edukans Foundation,Nairobi,Kenya.

O'Connor, P.J., and Trussell, S.T. (2005) "The Marketing of Vocational Education. "VOCATIONAL EDUCATION JOURNAL, 62(8), 31-32.

OECD (2009) "Learning for Jobs OECD review of Switzerland, 2009" (PDF). Oecd.org. Retrieved 2016-02-06.

Ogula, P. A. (2005). Research Methods. Nairobi: CUEA Publications.

Oni, A. A., \& Adetoro, J. A. (2015). The effectiveness of student involvement in decision making and university leadership: A comparative analysis of 12 universities in Southwest Nigeria. Journal of Student Affairs in Africa, 3(1), 65-81.

Opiyo.S (2013). Contribution of Youth Enterprise Development Fund on Youth Empowerment. University of Nairobi, Kenya.

Owano,A (2012). Education programs for employment: the contribution of the youth polytechnic education programs to youth employment. Kenyatta University, Kenya.

Owen, W.B. (2012). Sir Sidney Lee, ed. William Ford Robinson Stanley. Policy Reviews of Vocational Education and Training (VET) 'Second Supplement. III (NEIL-YOUNG). London: Smith, Elder \& Co.

Owens, L. K. (2002). Introduction to Survey Research Design. Qualitative Approaches. Nairobi: Acts Press.

Pitt, V., Powis, D., Levett-Jones, T., \& Hunter, S. (2012). Factors influencing nursing students' academic and clinical performance and attrition: an integrative literature review. Nurse Education Today, 32(8), 903-913.

Quasisie, G (2010). Be innovative in the teaching of science. Ghana News Agency, Ghana.

Read, B (2009). The chronicle of higher education programs report. The chronicle of higher education programs, USA.

Rigo, G. E., Pedron, C. D., Caldeira, M., \& Araújo, C. C. S. D. (2016). CRM adoption in a higher education institution. JISTEM-Journal of Information Systems and Technology Management, 13(1), 45-60.

Sharpe, D. (1993), "Image Control: Teachers and Staff Have the Power to Shape Positive Thinking." Vocational Education Journal 68, no. 1 (January 1993): 26-27.

Shields, C.J. (1989) "How to Market Vocational Education." CURRICULUM REVIEW (November 1989): 3-5

Silberman, H.F. (1986) "Improving the Status of High School Vocational Education." EDUCATIONAL HORIZONS 65. 
Stensaker, B 2008, 'Outcomes of Quality assurance: A discussion of knowledge, methodology and validity', Quality in Higher Education, 14 (1), 5-13.

Turkey 2012. 'Technical and Vocational Education and Training (TVET)'. Oecd.org. Retrieved 2016-02-06.

Tuttle, F.T. (1987), "Let's Get Serious about Image-Building." Vocational Education Journal, 62(8),11.

UNESCO (2005). Challenges of Implementing FPE in Kenya: Assessment Report. Graphics Print, Paris.

UNESCO (2012). TVET mission, legislation and national policy or strategy. United Nations education programs Scientific and Cultural Organization, Nairobi, Kenya.

UNESCO (2017). "Technical and Vocational Education and Education (TVET)". www.unesco.org. Retrieved 1 April 2017.

Walubengo, J (2007). Challenges and constraints facing youth polytechnics. A presentation at Jacaranda Hotel. Nairobi, Kenya.

Wambua, P., \& Kalai, J. M. (2017). Influence of Principals' Involvement of Students in Decision Making on Discipline in Secondary Schools, Kenya. European Scientific Journal, ESJ, 13(22).

Wanjohi, A (2013). Challenges facing Kenya in education programs for all. Kenya Projects Organization, Nairobi, Kenya.

West Virginia Department of education programs (2010). West Virginia Career and Technical education programs Global 21 Achievement Assessment Program. West Virginia Department of education programs, Virginia, USA.

Wilhelm (2008) World Class Apprenticeships. The Government's strategy for the future of Apprenticeships in England. DIUS/DCSF, 2008

Wolf, A. (2011). Review of Vocational education programs. The Wolf Report, London, England.

Wolf, A. (2002), Does Education Matter? Myths about Education and Economic Growth London: Penguin. 